\title{
PROMOSI PARIWISATA OLEH DUTA WISATA “JEGEG BAGUS KLUNGKUNG" PADA MASA NEW NORMAL
}

\author{
Luh Ade Syah Sugiarni \\ Universitas Udayana \\ Email: adesyahridzat@gmail.com \\ Putu Anom \\ Universitas Udayana \\ Email: putuanom@unud.ac.id \\ Ida Bagus Ketut Surya \\ Universitas Udayana \\ Email: idabgssurya@unud.ac.id
}

\begin{abstract}
Jegeg Bagus Klungkung (JBK) is a representative of the young generation in Klungkung Regency as a tourism ambassador with the aim of being an extension of the promotion of tourist destinations in Klungkung Regency. This study aims to describe the roles and constraints faced by JBK in promoting tourist destinations in Klungkung Regency during new normal period, as well as to formulate a strategic role for JBK in maximizing their role as tourism ambassadors. This study uses the promotion mix theory and strategic planning generated from the SWOT analysis. The relevant approach used in this research is a qualitative approach. Data were collected through observation, interview, documentation, and questionnaires. Primary data were obtained through interviews and filling out questionnaires by JBK and tourism stakeholders. Secondary data is obtained through documents, journals and articles. The study found that JBK has done their role as tourism ambassadors through its advertising and public relations on promotion mix. The obstacles experienced consist of external and internal constraints. The strategic role resulting from the SWOT analysis places JBK's position in that JBK should use an intensive strategic role in market penetration and market development, besides being able to diversify the products or services offered.
\end{abstract}

Keywords: JBK, Tourism Promotion, New Normal. 


\section{Pendahuluan}

Jegeg Bagus Klungkung (JBK) merupakan duta wisata yang diwakili oleh generasi muda di Kabupaten Klungkung untuk mempromosikan pariwisata dan budaya yang dimiliki oleh Kabupaten Klungkung. Sebagai kelompok duta wisata yang memiliki sumber daya manusia (SDM) yang muda, keatif dan inovatif, JBK diharapkan mampu untuk memberikan kontribusi bagi perkembangan pariwisata di Kabupaten Klungkung. Pemilihan JBK diprakarsai oleh pemilihan Jegeg Bagus Bali pada tahun 2005 yang dilakukan dengan menggunakan system road show, kemudian pada tahun-tahun berikutnya dilaksanakan secara mandiri oleh masing-masing Dinas Pariwisata (Dispar) pada tiap Kabupaten di Bali.

Terdapat 3 indikator utama penilaian dalam pemilihan JBK, yaitu smart, charming, dan hospitable. Dengan memiliki tiga kualitas tersebut, JBK sepatutnya dapat melaksanakan peran mereka sebagai duta wisata dalam mempromosikan destinasi wisata di Kabupaten Klungkung.

Salah satu stakeholder pariwisata yaitu Bupati Kabupaten Klungkung, Bapak Suwirta dalam suatu artikel berita yang berjudul "Bupati Suwirta Harapkan Jegeg Bagus Tidak Hanya Bermodal Kecantikan dan Ketampanan", menyatakan bahwa JBK belum diberdayakan secara maksimal dan masih hanya sebatas pajangan (Klungkungkab, 2020). Untuk menjelaskan permasalahan ini, belum terdapat kajian yang menjelaskan peran JBK dalam mempromosikan destinasi wisata di Kabupaten Klungkung. Sebagai ajang pemilihan duta wisata yang didukung penuh oleh pemerintah, JBK dituntut agar dapat memperlihatkan peran nyata mereka sebagai duta wisata.

Pemilihan Jegeg Bagus Klungkung diadakan secara rutin setiap tahunnya, namun pemilihan yang sedang berlangsung pada tahun 2020 terpaksa terhenti karena terjadinya pandemi Covid-19. Adanya pelarangan untuk menyelenggarakan kegiatan 
yang dapat mengundang kerumunan, serta alokasi dana yang dialihkan untuk penanganan gawat darurat Covid-19 menyebabkan dibatalkannya pemilihan JBK 2020.

Merebaknya virus Covid-19 menyebabkan seluruh kegiatan perjalanan pariwisata tepaksa dihentikan. Dengan adanya fenomena ini, mengubah kebiasaan masyarakat dalam beraktivitas. Salah satunya dengan diterapkannya perlakuan pembatasan kegiatan masyarakat (PPKM) serta penerapan protokol kesehatan yang ketat. Fenomena ini menimbulkan lahirnya suatu istilah yang disebut dengan "masa new normal".

Kondisi ini tentunya sangat mengancam industri pariwisata dan seluruh stakeholder pariwisata. Salah satu langkah yang masih dapat dilakukan adalah dengan melakukan promosi destinasi wisata, agar pada saat penyebaran Covid-19 telah menurun dan terhenti, suatu destinasi wisata dapat melaksanakan aktivitas kepariwisataannya dengan optimal kembali.

Dalam keadaan seperti ini, JBK diharapkan mampu memberikan kontribusi dalam membantu Dispar Klungkung untuk mempromosikan destinasi wisata di Kabupaten Klungkung.

Berdasarkan hal tersebut, paper ini fokus membahas tentang peran dan upaya JBK dalam mempromosikan destinasi wisata di Kabupaten Klungkung pada masa new normal, kendala yang dialami, serta perumusan peran strategis JBK dalam mempromosikan destinasi wisata di Kabupaten Klungkung pada masa new normal.

\section{Konsep dan Landasan Teori}

Satriawan (2013: 39) mendefinisikan duta wisata sebagai figur pariwisata yang melewati beragam proses pemilihan yang diikuti oleh generasi muda. Tugas dari duta 
wisata yaitu sebagai perpanjangan tangan pemerintah untuk mempromosikan potensi pariwisata dengan tujuan meningkatkan kunjungan wisatawan.

Jegeg Bagus merupakan suatu sarana bagi generasi muda terpilih dengan kualitas, keunggulan, dan keberanian untuk keluar dari zona nyaman dan mampu meningkatkan kemampuan diri khususnya di bidang pariwisata berdasarkan "Tri Hita Karana" (Jegegbagusbali, 2021)

Wattimena et al (2015) menyatakan bahwa seorang duta wisata, dalam hal ini adalah JBK, memiliki peran layaknya seorang praktisi public relation, dimana tugas yang diemban tidak jauh berbeda, yaitu memperkenalkan dan mempromosikan suatu daerah ke khalayak umum melalui komunikasi, dimana mereka berada di bawah pimpinan Dinas Pariwisata Kabupaten Klungkung. Ruslan (2016:5) menjelaskan bahwa praktik public relation merupakan seni dan ilmu pengetahuan sosial yang dapat dimanfaatkan untuk menganalisis kecenderungan, memprediksi konsekuensikonsekuensi, menasihati pemimpin organisasi, dan melaksanakan aktivitas yang direncanakan sehubungan dengan kegiatan-kegiatan yang melayani, baik untuk kepentingan internal maupun kepentingan eksternal atau publik. Praktisi public relation akan melakukan fungsi-fungsi manajemen perusahaan, yang memiliki peran utama sebagai communicator, relationship, back up management, serta good image maker. Ruslan (2016:14) menyatakan bahwa seorang praktisi Humas (Public Relation Practitioner) harus memiliki beberapa keterampilan khusus, diantaranya sebagai creator, conceptor, mediator, serta problem solver.

Sebagai duta wisata, JBK juga memiliki tugas untuk membantu kegiatan promosi wisata yang dilakukan oleh Dinas Pariwisata Kabupaten Klungkung. Buchory dan Saladin (dalam Diyatma dan Rahayu, 2017:176) mengatakan bahwa promosi merupakan bagian dari bauran pemasaran dengan tujuan memberitahukan, membujuk, dan mengingatkan mengenai suatu produk perusahaan atau organisasi. 
Pada tahun 2020, terjadi suatu pandemi global akibat dari penyebaran virus Covid-19. Dari pandemi ini, timbul suatu kebiasaan masyarakat baru yang disebut dengan masa new normal. Ketua Tim Pakar Gugus Tugas Percepatan Penanganan Covid-19, Wiku Adisasmita (2020 dalam Fajar, 2020), menyebutkan bahwa masa new normal merupakan masa dimana terjadi perubahan perilaku untuk tetap menjalankan aktivitas normal, namun terdapat penerapan protokol kesehatan untuk langkah preventif penularan virus Covid-19. Terjadi nya masa new normal ini mengakibatkan seluruh kegiatan perjalanan terutama perjalanan pariwisata mengalami kemerosotan. Seluruh stakeholder pariwisata berusaha untuk melakukan upaya terbaik dalam mempromosikan destinasi maupun produk atau jasa pariwisata yang mereka miliki agar pada saat seluruh kegiatan perjalanan wisata telah kembali normal, aktivitas kepariwisataan dapat berjalan secara maksimal.

Selama masa new normal, seluruh stakeholder, terutama dari sisi kepemerintahan mengalami kendala promosi yang diakibatkan oleh penyebaran virus Covid-19, tak terkecuali bagi Dinas Pariwisata Kabupaten Klungkung, dimana anggaran untuk promosi pariwisata dialokasikan untuk penanganan gawat darurat Covid-19. JBK sebagai perpanjangan tangan Dinas Pariwisata Kabupaten Klungkung tentunya mengalami kendala untuk mempromosikan destinasi wisata di Kabupaten Klungkung pada masa new normal. Hansen dan Mowen (2013, dalam Suneth, 2016: 16) menyatakan bahwa terdapat dua jenis kendala berdasarkan asalnya yaitu kendala eksternal dan kendala internal.

Undang-Undang Kepariwisataan No. 10. Tahun 2009 (pasal 1 ayat 6) menyatakan bahwa destinasi pariwisata merupakan wilayah geografis yang terletak dalam satu atau lebih wilayah administratif fasilitas umum, fasilitas pariwisata, aksesibilitas, serta masyarakat yang saling terkait dan melengkapi terwujudnya pariwisata. 
Teori yang digunakan dalam penelitian ini adalah perencanaan strategis dan bauran promosi. Rangkuti (2018: 3) menyebutkan bahwa perencanaan strategis merupakan rangkaian analisis, perumusan dan evaluasi strategi-strategi. Perencanaan strategis JBK dirumuskan dari hasil analisis faktor internal dan eksternal dalam mempromosikan destinasi wisata di Kabupaten Klungkung pada masa new normal. Secara lebih ringkas perencanaan strategis merupakan proses perencanaan jangka panjang yang disusun dan digunakan untuk menentukan dan mencapai tujuan-tujuan organisasi (Handoko, 2003).

Dalam melasanakan aktivitas promosi, terdapat beberapa unsur dari bauran promosi yang dapat digunakan oleh JBK. Bauran promosi menurut Gary dan Kotler (2012:432) adalah perpaduan spesifik antara iklan, promosi penjualan, hubungan masyarakat, penjualan personal, dan sarana pemasaran langsung yang digunakan untuk mengkomunikasikan nilai pelanggan secara persuasif dan membangun hubungan pelanggan.

\section{Metode Penelitian}

Pendekatan penelitian ini menggunakan pendekatan kualitatif dengan metode penelitian deskriptif kualitatif, mencari gambaran umum membandingkan data yang didapat serta mencari hubungan setiap data yang diperoleh, serta menggunakan analisis faktor internal dan eksternal untuk analisis SWOT. Penelitian ini mengkaji mengenai peran dan upaya JBK dalam mempromosikan destinasi wisata di Kabupaten Klungkung, kendala yang dialami serta analisis perumusan peran strategis dalam mempromosikan destinasi wisata di Kabupaten Klungkung pada masa new normal. Lokasi penelitian berada di Kabupaten Klungkung. Informan yang terlibat dalam penelitian ini sejumlah 16 orang yang terdiri dari pengurus paguyuban JBK, panitia pemilihan JBK 2020, finalis JBK tahun 2020, staff dari Dinas Pariwisata Kabupaten Klungkung, akademisi, perwakilan stakeholder lembaga pariwisata, media, 
serta pekerja pariwisata dan masyarakat di Kabupaten Klungkung. Teknik pengumpulan data yang digunakan adalah observasi, wawancara dan studi dokumentasi. Informan ditentukan dengan menggunakan teknik purposive sampling. Analisis data yang digunakan yaitu deskriptif kualitatif, analisis faktor internal dan eksternal (IFAS dan EFAS) serta analisis SWOT (strength, weakness, opportunity, threat).

Tahap awal yang dilakukan adalah mencari informasi mengenai informan dan menyiapkan daftar pertanyaan dalam pedoman wawancara, melakukan studi dokumentasi yaitu mengumpulkan data terkait profil JBK, membaca artikel atau berita terkait JBK di internet dan melihat aktivitasnya pada masing-masing akun media sosial yang dimiliki seperti instagram, youtube, dan facebook. Dalam daftar pertanyaan, peneliti juga memberikann pertanyaan mengenai unsur-unsur yang menjadi indikator kekuatan, kelemahan, peluang serta ancaman yang dimiliki dan dihadapi oleh JBK dalam mempromosikan destinasi wisata di Kabupaten Klungkung pada masa new normal. Seluruh unsur kekuatan, kelemahan, peluang dan ancaman akan dijadikan dasar dalam membuat kuisioner penilaian bobot dan rating untuk menentukan peran strategis JBK. Reduksi data diawali dengan mendengarkan hasil rekaman wawancara, membaca jawaban informan pada pedoman wawancara, melihat hasil catatan lapangan pada saat observasi, memilih dan merangkum hal-hal yang penting terkait peran dan kendala JBK dalam promosi. Matrik analisis faktor internal (IFAS) dan matrik analisis faktor eksternal (EFAS) digunakan untuk mengetahui kekuatan, kelemahan, peluang dan ancaman, selanjutnya analisis SWOT (Strength, Weaknesses, Opportunites, Threat) menghasilkan strategi alternatif bagi JBK dalam mempromosikan destinasi wisata di Kabupaten Klungkung pada masa new normal. 


\section{Pembahasan}

\section{Peran dan Upaya Jegeg Bagus Klungkung dalam Mempromosikan Destinasi Wisata di Kabupaten Klungkung pada Masa New Normal}

JBK sebagai duta wisata di Kabupaten Klungkung telah berperan dalam upaya mempromosikan destinasi wisata di Kabupaten Klungkung pada masa new normal melalui program kerja berupa pembuatan video promosi di berbagai destinasi wisata di Kabupaten Klungkung yang kemudian diunggah di berbagai media sosial yang dimiliki oleh JBK seperti facebook, instagram dan youtube. Selain itu, pemilihan JBK 2020 menyertakan pembuatan video promosi sebagai salah satu syarat untuk mengikuti pemilihan, dimana video-video tersebut juga diunggah ke akun sosial media JBK. Pembuatan video promosioleh JBK didanai dengan melakukan kerjasama berupa sponsorship dengan berbagai pengusaha di bidang pariwisata. Respon dari pengusaha yang pernah melakukan kerjasama sponsorship dengan JBK menunjukkan bahwa dari kerjasama tersebut dapat menmbah target pasar mereka terutama dari instansi pemerintahan, namun ada pula yang belum merasakan dampak signifikan dari kerjasama yang dilakukan. Upaya promosi yang dilakukan oleh JBK mendapat berbagai respon dari pihak stakeholder pariwisata dan masyarakat umum. Terdapat pihak-pihak yang telah mengetahui kontribusi JBK berupa pembuatan video promosi, namun terdapat pula pihak-pihak yang kurang mengetahui upaya promosi yang telah dilakukan oleh JBK. Dalam bauran promosi, JBK dapat memaksimalkan bauran periklanan (advertising) dan hubungan masyarakat (public relation) dalam promosi pada masa new normal. 


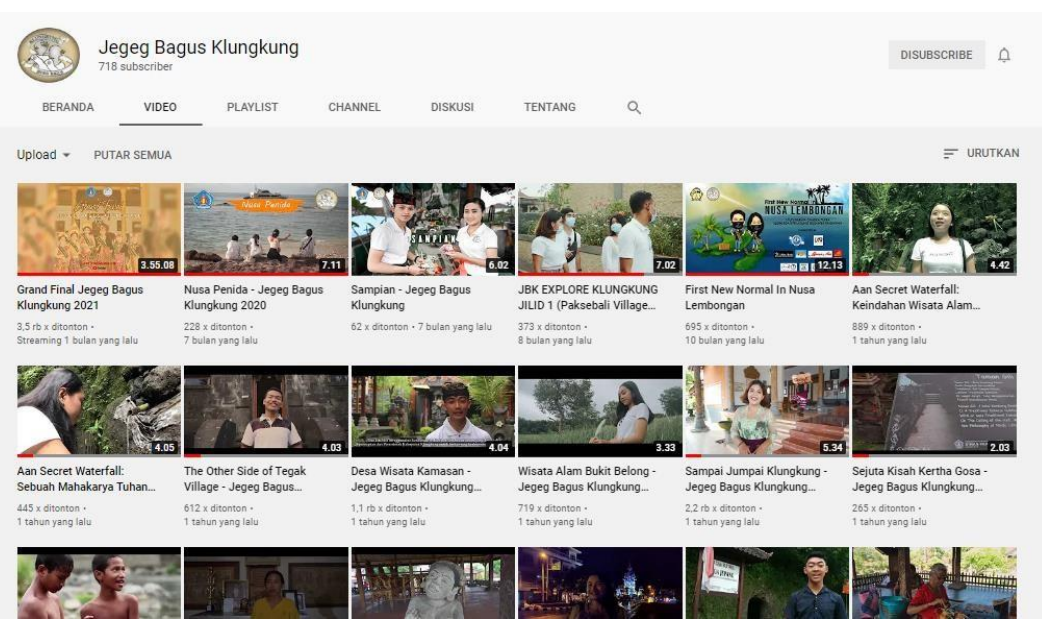

Gambar 1. Video Unggahan dari kontestan JBK 2020 (Sumber: JBK, 2021)

\section{Kendala Jegeg Bagus Klungkung dalam Mempromosikan Destinasi Wisata di Kabupaten Klungkung pada Masa New Normal}

Kendala yang dihadapi oleh JBK dalam mempromosikan destinasi wisata di Kabupaten Klungkung pada masa new normal terdiri dari satu kendala ekternal dan tiga kendala internal. Kendala eksternal yang dihadapi oleh JBK adalah penyesuaian dengan masa new normal dan penyebaran virus Covid-19 yang belum tuntas. Meskipun JBK telah melakukan upaya promosi secara digital melalui sosial media, namun jika kondisi global belum memungkinkan untuk melakukan perjalanan wisata, maka upaya promosi yang dilakukan akan semakin lama untuk memberikan dampak bagi kepariwisataan di Kabupaten Klungkung. Kendala internal yang dihadapi oleh JBK adalah masalah pendanaan, bentuk organisasi yang belum kuat dan kepentingan serta kesibukan pribadi masing-masing anggota. Kendala pendanaan yang terjadi adalah akibat dari anggaran promosi Dinas Pariwisata Kabupaten Klungkung yang dialokasikan untuk penanganan gawat darurat Covid19. Kendala mengenai bentuk organisasi yang belum kuat menjadikan kurang optimalnya pemberdayaan anggota paguyuban JBK yang berjumlah 149 orang yang 
seharusnya dapat bekerjasama dalam melakukan upaya promosi sebagai paguyuban duta wisata. Selain itu, kepentingan dan kesibukan pribadi anggota JBK menjadikan kurang intensnya upaya promosi yang dilakukan oleh JBK yang juga menyebabkan pengelolaan promosi digital melalui sosial media menjadi kurang intens dan responsif dalam menanggapi komentar- komentar yang didapatkan dari video promosi pariwisata yang diunggah.

\section{Peran Strategis Jegeg Bagus Klungkung dalam Mempromosikan Destinasi Wisata di Kabupaten Klungkung pada Masa New Normal}

Faktor internal yang digunakan pada analisis matriks IFAS adalah sebanyak 15 faktor, dan memperoleh nilai 3.016. Angka tersebut menunjukkan bahwa faktor internal lingkungan JBK dalam melakukan promosi pada masa new normal masuk dalam kategori kuat. Faktor internal ini terdiri dari 8 faktor kekuatan dan 7 faktor kelemahan (lihat Tabel 1).

Faktor eksternal yang digunakan pada analisis matriks EFAS adalah sebanyak 15 faktor, dan memperoleh nilai 2.780. Angka tersebut menunjukkan bahwa faktor eksternal lingkungan masuk dalam kategori sedang atau rata-rata. Faktor eksternal ini terdiri dari 8 faktor peluang dan 7 faktor ancaman (lihat Tabel 2).

Tabel 1. Analisis Matriks IFAS Jegeg Bagus Klungkung

\begin{tabular}{|c|c|c|c|c|}
\hline \multicolumn{5}{|c|}{ Kekuatan } \\
\hline No. & Faktor Internal & Bobot (B) & Rating (R) & $\mathbf{B} \times \mathbf{R}$ \\
\hline 1 & Kemampuan Komunikasi & 0,068 & 2.867 & 0.195 \\
\hline 2 & $\begin{array}{l}\text { Berada di bawah naungan Dinas Pariwisata } \\
\text { Kabupaten Klungkung }\end{array}$ & 0,075 & 3.667 & 0.275 \\
\hline 3 & $\begin{array}{l}\text { SDM berusia muda dan berpotensi } \\
\text { untuk dikembangkan }\end{array}$ & 0.076 & 3.800 & 0.288 \\
\hline 4 & $\begin{array}{l}\text { Sosial media yang telah memiliki cukup } \\
\text { banyak pengikut }\end{array}$ & 0,070 & 3.533 & 0.247 \\
\hline
\end{tabular}




\begin{tabular}{|c|c|c|c|c|}
\hline 5 & $\begin{array}{l}\text { Kegiatan tahunan yang telah lama } \\
\text { berlangsung }\end{array}$ & 0,062 & 3.000 & 0.186 \\
\hline 6 & $\begin{array}{l}\text { Anggota Paguyuban JBK yang cukup } \\
\text { banyak }\end{array}$ & 0.058 & 2.800 & 0.162 \\
\hline 7 & $\begin{array}{l}\text { Prestasi anggota sebelum menjadi } \\
\text { anggota JBK }\end{array}$ & 0,062 & 2.867 & 0.178 \\
\hline 8 & Charming, Smart and Hospitable & 0,075 & 3.333 & 0.250 \\
\hline & Total Kekuatan & 0.546 & & 1.782 \\
\hline \multicolumn{5}{|c|}{ KELEMAHAN } \\
\hline 1 & Bentuk organisasi & 0.059 & 3.000 & 0.178 \\
\hline 2 & Prioritas utama lain dari anggota JBK & 0.064 & 3.267 & 0.210 \\
\hline \multirow[t]{2}{*}{3} & Tidak ada MoU antara JBK dengan & 0.06 & & \\
\hline & Dinas Pariwisata & & 3.133 & 0.188 \\
\hline 4 & $\begin{array}{l}\text { Pengalaman mempromosikan destinasi } \\
\text { wisata secara professional }\end{array}$ & 0.072 & 2.467 & 0.178 \\
\hline 5 & Pelatihan yang tidak berkelanjutan & 0.072 & 2.467 & 0.178 \\
\hline 6 & $\begin{array}{l}\text { Pengelolaan Sosial Media yang kurang } \\
\text { intens dan responsif }\end{array}$ & 0.061 & 2.467 & 0.150 \\
\hline \multirow[t]{2}{*}{7} & Kegiatan promosi yang tidak rutin & 0.066 & 2.333 & 0.154 \\
\hline & Total Kelemahan & 0.454 & & 1.233 \\
\hline \multicolumn{4}{|c|}{ Total Nilai Tertimbang Faktor Internal } & 3.016 \\
\hline
\end{tabular}

Sumber: Peneliti, 2021

Tabel 2. Analisis Matriks EFAS Jegeg Bagus Klungkung

\begin{tabular}{|c|c|c|c|c|}
\hline \multicolumn{5}{|c|}{ PELUANG } \\
\hline No. & Faktor Eksternal & Bobot (B) & Rating (R) & $\mathbf{B} \times \mathbf{R}$ \\
\hline 1. & $\begin{array}{l}\text { Jangkauan kepada pasar yang lebih luas terutama } \\
\text { pada generasi muda }\end{array}$ & 0.067 & 3.400 & 0.228 \\
\hline 2. & Perkembangan teknologi dan informasi & 0.074 & 3.733 & 0.267 \\
\hline 3. & $\begin{array}{l}\text { Mendapatkan bibit-bibit generasi muda yang kreatif } \\
\text { setiap tahunnya }\end{array}$ & 0.067 & 3.267 & 0.219 \\
\hline 4. & Memberikan citra positif & 0.064 & 2.600 & 0.166 \\
\hline
\end{tabular}




\begin{tabular}{|c|c|c|c|c|}
\hline 5. & Adanya kontes nasional lain yang dapat diikuti & 0.062 & 2.667 & 0.165 \\
\hline 6. & Memberikan motivasi bagi generasi muda & 0.057 & 2.733 & 0.156 \\
\hline 7. & Kerja sama dengan pengusaha di bidang pariwisata & 0.067 & 3.533 & 0.237 \\
\hline 8 . & $\begin{array}{l}\text { Kerja sama dalam bidang promosi dengan lembaga } \\
\text { pariwisata terkait. }\end{array}$ & 0.074 & 3.000 & 0.222 \\
\hline \multicolumn{2}{|c|}{ Total Peluang } & 0.532 & & 1.667 \\
\hline \multicolumn{5}{|c|}{ ANCAMAN } \\
\hline 1 . & Adaptasi dengan masa new normal & 0.071 & 1.933 & 0.137 \\
\hline 2. & $\begin{array}{l}\text { Anggapan masyarakat bahwa JBK masih sekedar } \\
\text { pajangan }\end{array}$ & 0.061 & 3.200 & 0.195 \\
\hline 3. & $\begin{array}{l}\text { Ruang gerak JBK yang masih bergantung pada } \\
\text { Dinas Pariwisata Kabupaten Klungkung }\end{array}$ & 0.067 & 2.800 & 0.188 \\
\hline 4. & $\begin{array}{l}\text { Anggaran yang terbatas dari Dinas Pariwisata } \\
\text { Kabupaten Klungkung }\end{array}$ & 0.069 & 2.333 & 0.159 \\
\hline 5. & Persaingan dengan duta wisata di Kabupaten lain. & 0.059 & 2.800 & 0.165 \\
\hline 6. & $\begin{array}{l}\text { Penyebaran virus Covid-19 yang masih belum } \\
\text { tuntas di berbagai wilayah di berbagai wilayah }\end{array}$ & 0.072 & 1.733 & 0.125 \\
\hline 7. & $\begin{array}{l}\text { Pihak sponsor yang kurang merasakan manfaat } \\
\text { dari kerjasama dengan JBK }\end{array}$ & 0.069 & 2.067 & 0.143 \\
\hline \multicolumn{2}{|c|}{ Total Ancaman } & 0.468 & & 1.111 \\
\hline \multicolumn{4}{|c|}{ Total Nilai Tertimbang Faktor Eksternal } & 2.780 \\
\hline
\end{tabular}

Sumber: Peneliti

\section{Analisis Matriks Internal-Eksternal (IE)}

Analisis matriks IFAS dan EFAS memperlihatkan faktor internal dan Jegeg Bagus Klungkung berada pada wilayah 1 dalam sel IV dimana persepsi yang dapat digambarkan adalah kondisi tumbuh dan berkembang (Grow and build). Strategi intensif (penetrasi pasar, pengembangan pasar, dan pengembangan produk) atau integratif (integrasi ke belakang, integrasi ke depan, dan integrasi horizontal) dapat menjadi yang paling tepat untuk divisi ini. Berikut adalah beberapa rumusan peran 
strategis yang dapat dilakukan oleh JBK dari posisi yang telah ditentukan pada matrik I-E.

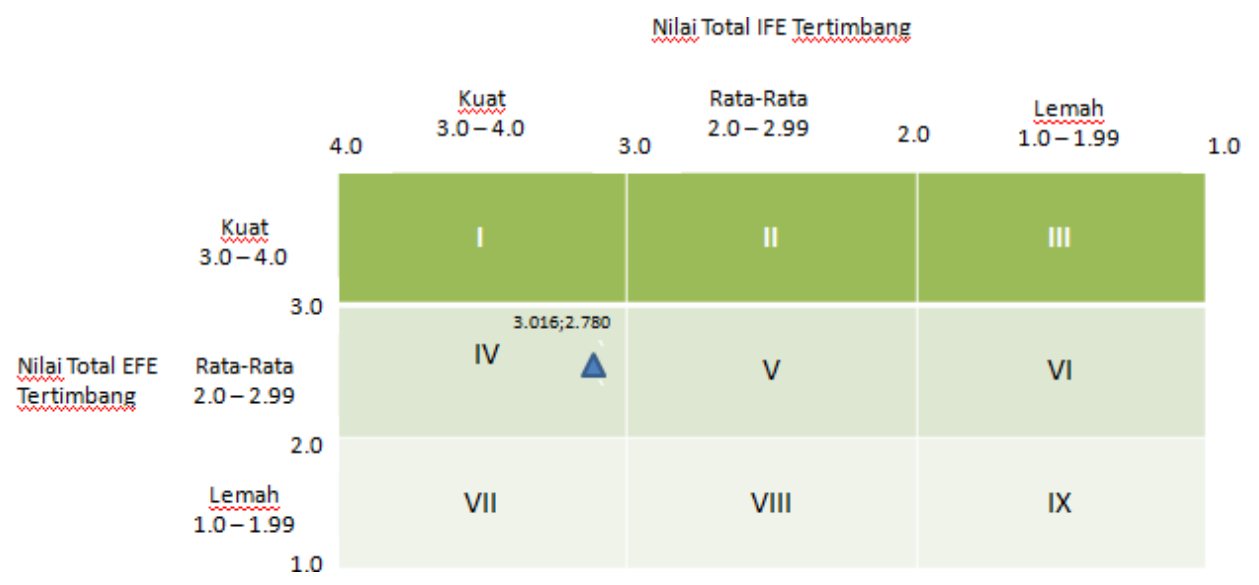

Gambar 2. Matriks I-E Sumber: David, 2017

\section{Rumusan Peran Strategis berdasarkan Matrik I-E}

1) Melakukan penetrasi pasar yang telah dikuasai dan menyasar pasar-pasar baru Wawancara yang dilakukan dengan bidang pemasaran pariwisata Kabupaten Klungkung beserta anggota JBK, selama ini target pasar untuk kepariwisataan di Kabupaten Klungkung menyasar kepada wisatawan yang berorientasi pada wisata alam, hal serupa diungkapkan oleh penelitian yang dilakukan oleh Krisnadevi, et al (2020) dengan mayoritas kunjungan wisatawan yang didominasi oleh turis asal Jerman. JBK bersama dengan Dinas Pariwisata Kabupaten Klungkung dapat dengan lebih intens melakukan penetrasi kepada segmentasi pasar peminat wisata alam, serta melakukan penetrasi kepada pasar-pasar yang belum dikuasai, seperti wisatawan yang memiliki preferensi kepada wisata sejarah dan budaya. 
2) Melakukan diversifikasi dan pengembangan produk (destinasi wisata) dan atau jasa baru (upaya promosi)

JBK dan Dinas Pariwisata Kabupaten Klungkung dapat mengembangkan potensi pariwisata seperti seni lukis kamasan, kerajinan pis bolong, kerajinan kain endek dan yang lainnya dengan membuat suatu paket wisata yang dapat memberikan pengalaman yang mengesankan bagi wisatawan. Dari segi jasa yang ditawarkan oleh JBK itu sendiri, JBK dapat memperluas media dan cara promosi yang dilakukan, seperti memanfaatkan perkembangan teknologi informasi.

\section{3) Melakukan integrasi ke hulu dan ke hilir}

JBK sebaiknya secara agresif melakukan kerjasama ke hullu dengan lembaga dan instansi di bidang pariwisata, seperti Dinas Pariwisata, BPPD Kabupaten Klungkung, PHRI Kabupaten Klungkung, ASITA Kabupaten Klungkung, POKDARWIS masing-masing desa wisata di Klungkung, serta ke hilir dengan pengusaha di bidang pariwisata dalam mempromosikan destinasi pariwisata di Kabupaten Klungkung pada masa new normal.

\section{Analisis Matriks SWOT}

Pilihan peran strategis yang dapat diambil oleh JBK dapat digambarkan dalam matriks SWOT seperti dicantumkan pada Tabel 3. 
Tabel 3. Matriks SWOT

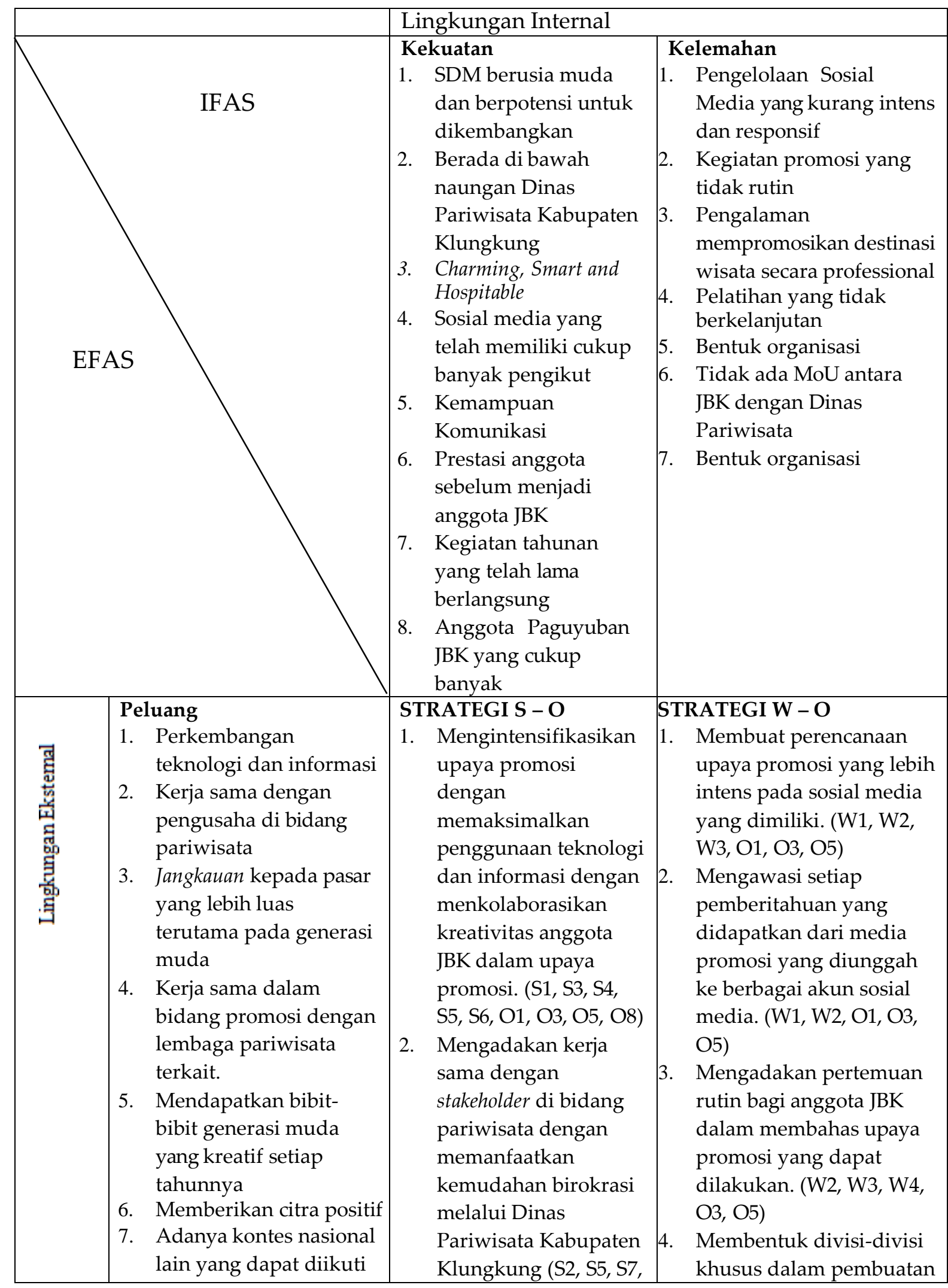




\begin{tabular}{|c|c|c|}
\hline $\begin{array}{l}\text { 8. Memberikan motivasi } \\
\text { bagi generasi muda }\end{array}$ & $\begin{array}{l}\mathrm{O} 2, \mathrm{O} 4, \mathrm{O} 6) \\
\text { 3engembangkan } \\
\text { jangkauan kepada } \\
\text { pasar yang lebih luas } \\
\text { melalui sosial media } \\
\text { (S1, S3, S4, S5, S8, O1, } \\
\mathrm{O} 3, \mathrm{O} 5, \mathrm{O} 7)\end{array}$ & \begin{tabular}{|l} 
media promosi, \\
pengelolaan sosial media, \\
dan komunikator dengan \\
stakeholder di bidang \\
pariwisata. (W1, W2, W3, \\
W4, W5, W7, O1, O5) \\
5. \\
Membentuk kerjasama \\
yang dapat memberikan \\
keuntungan bagi JBK dan \\
stakeholder di bidang \\
pariwisata (W6, O2, O4)
\end{tabular} \\
\hline $\begin{array}{ll}\text { Ancaman } \\
\text { 1. } \\
\text { Penyebaran virus } \\
\text { Covid- } \\
19 \text { yang masih belum } \\
\text { tuntas di berbagai } \\
\text { wilayah di berbagai } \\
\text { wilayah } \\
\text { 2. Adaptasi dengan masa } \\
\text { new normal } \\
\text { 3. Pihak sponsor yang } \\
\text { kurang merasakan } \\
\text { manfaat dari kerjasama } \\
\text { dengan JBK } \\
\text { Ruang gerak JBK yang } \\
\text { masih bergantung pada } \\
\text { Dinas Pariwisata } \\
\text { Kabupaten Klungkung } \\
\text { Anggaran yang terbatas } \\
\text { dari Dinas Pariwisata } \\
\text { Kabupaten Klungkung } \\
\text { Anggapan masyarakat } \\
\text { bahwa JBK masih } \\
\text { sekedar pajangan } \\
\text { 7. Persaingan dengan } \\
\text { duta wisata di } \\
\text { Kabupaten lain }\end{array}$ & $\begin{array}{l}\text { STRATEGI S - T } \\
\text { 1. } \text { Memberikan edukasi } \\
\text { dan informasi melalui } \\
\text { berbagai media } \\
\text { promosi bahwa } \\
\text { destinasi pariwisata di } \\
\text { Kabupaten } \\
\text { Klungkung telah } \\
\text { menerapkan protokol } \\
\text { kesehatan sesuai } \\
\text { dengan aturan yang } \\
\text { berlaku. (S1, S4, S5, S8, } \\
\text { T1, T2). } \\
\text { 2. Membuat suatu } \\
\text { bentuk promosi yang } \\
\text { lebih persuasif bagi } \\
\text { calon wisatawan yang } \\
\text { berniat membeli } \\
\text { produk/jasa dari } \\
\text { sponsor yang } \\
\text { bekerjasama dengan } \\
\text { JBK. (T3, T5, S4, S5) } \\
\text { 3. JBK lebih aktif dalam } \\
\text { mencari informasi } \\
\text { mengenai kesempatan- } \\
\text { kesempatan } \\
\text { melakukan kerjasama } \\
\text { di bidang promosi } \\
\text { wisata dengan } \\
\text { lembaga/instansi di } \\
\text { luar Dinas Pariwisata } \\
\text { (S1, S2, S3, S5, T4, T5, } \\
\text { T6) }\end{array}$ & 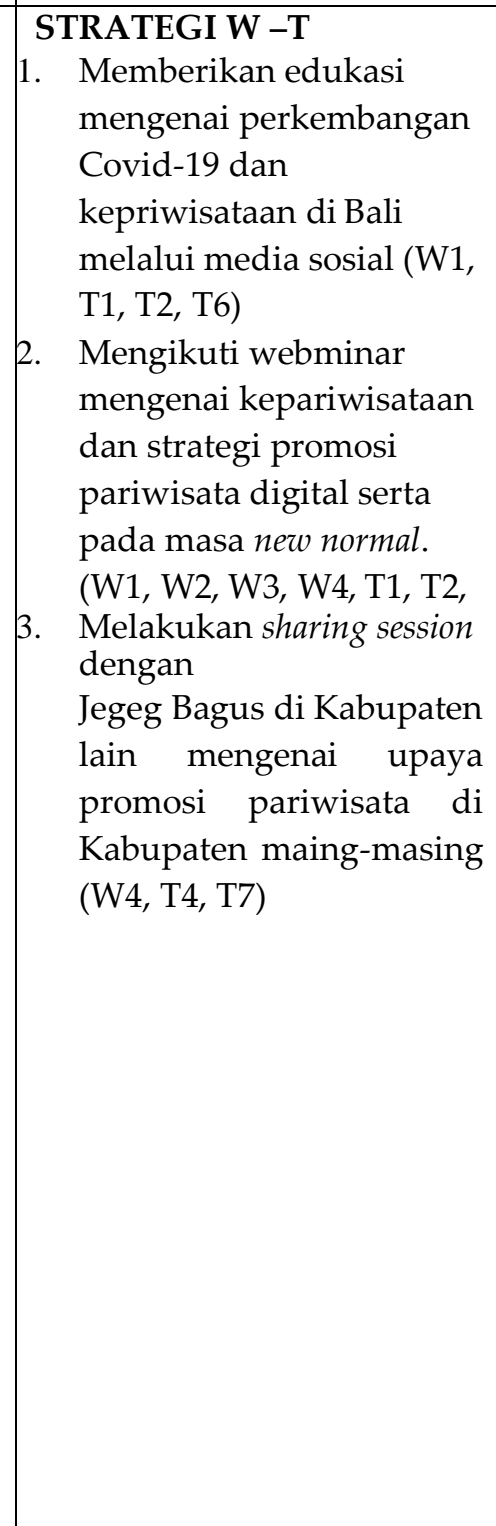 \\
\hline
\end{tabular}

Sumber: Peneliti, 2021

Berdasarkan pada analisis SWOT di atas menunjukkan bahwa alternatif strategi yang tercipta merupakan kombinasi dari faktor internal dan faktor eksternal 
yang kemudian disusun menjadi lebih rinci ke dalam bentuk program. Strategi yang sudah dijabarkan ke dalam bentuk program dapat dilihat pada Tabel 4 berikut:

\begin{tabular}{|c|c|c|}
\hline No. & Strategi & Program \\
\hline \multirow[t]{3}{*}{1.} & $\begin{array}{l}\text { Strategi SO } \\
\text { 1) Mengintensifikasikan upaya } \\
\text { promosi dengan memaksimalkan } \\
\text { penggunaan teknologi dan } \\
\text { informasi dengan } \\
\text { menkolaborasikan kreativitas } \\
\text { anggota JBK }\end{array}$ & $\begin{array}{l}\text { a. Memaksimalkan penggunaan fitur- } \\
\text { fitur yang tersedia pada sosial media } \\
\text { b. Membuat konten promosi yang } \\
\text { menarik mengenai kepariwisataan } \\
\text { di Klungkung (destinasi } \\
\text { pariwisata, sejarah, budaya, dll). } \\
\text { c. Mengeksplorasi pemanfaatan } \\
\text { perkembangan teknologi lain seperti } \\
\text { Augmented Reality dan } \\
\text { Virtual Reality. }\end{array}$ \\
\hline & $\begin{array}{l}\text { 2) Menjalin kerja sama dengan } \\
\text { stakeholder di bidang } \\
\text { pariwisata dengan } \\
\text { memanfaatkan kemudahan } \\
\text { birokrasi melalui Dinas } \\
\text { Pariwisata Kabupaten } \\
\text { Klungkung }\end{array}$ & $\begin{array}{l}\text { a. Membangun koneksi dengan stakeholder } \\
\text { pariwisata seperti pengusaha } \\
\text { pariwisata serta lembaga-lembaga } \\
\text { terkait seperti ASITA, PHRI, BPPD dan } \\
\text { lembaga lainnya. } \\
\text { b. Ikut meramaikan kegiatan } \\
\text { kepariwisataan yang dilakukan oleh } \\
\text { stakeholder pariwisata di } \\
\text { Kabupaten Klungkung }\end{array}$ \\
\hline & $\begin{array}{l}\text { 3) Mengembangkan jangkauan kepada } \\
\text { pasar yang lebih luas melalui sosial } \\
\text { media }\end{array}$ & $\begin{array}{l}\text { a. Memanfaatkan fitur "promote" } \\
\text { pada sosial media dengan memilih } \\
\text { demografi sesuai dengan market } \\
\text { segment kepariwisataan di } \\
\text { Kabupaten Klungkung. } \\
\text { b. Melakukan kolaborasi dengan } \\
\text { akun-akun pariwisata yang telah }\end{array}$ \\
\hline 2 & $\begin{array}{l}\text { Strategi ST } \\
\text { 1) Memberikan edukasi dan informasi } \\
\text { melalui berbagai media promosi } \\
\text { bahwa destinasi pariwisata di } \\
\text { Kabupaten Klungkung telah } \\
\text { menerapkan protokol kesehatan } \\
\text { sesuai dengan } \\
\text { aturan yang berlaku. }\end{array}$ & $\begin{array}{l}\text { a. Memberikan informasi mengenai } \\
\text { perkembangan penyebaran Covid- } \\
19 \text { di Indonesia khususnya di Bali } \\
\text { dan Klungkung } \\
\text { b. Memberikan informasi mengenai } \\
\text { perkembangan berbagai kegiatan } \\
\text { terkait dalam } \\
\text { mengantisipasi virus Covid-19 yang } \\
\text { dilakukan }\end{array}$ \\
\hline
\end{tabular}




\begin{tabular}{|c|c|c|}
\hline & & $\begin{array}{l}\text { seperti pemberian vaksin kepada } \\
\text { seluruh komponen masyarakat di } \\
\text { Bali khususnya di Kabupaten } \\
\text { Klungkung } \\
\text { c. Memberikan informasi mengenai syarat- } \\
\text { syarat berkunjung ke Bali khususnya } \\
\text { Kabupaten } \\
\text { Klungkung pada masa new normal }\end{array}$ \\
\hline & $\begin{array}{l}\text { 2) Membuat suatu bentuk promosi } \\
\text { yang lebih persuasif bagi calon } \\
\text { wisatawan yang berniat membeli } \\
\text { produk/jasa dari sponsor yang } \\
\text { bekerjasama dengan JBK }\end{array}$ & $\begin{array}{l}\text { a. Membuat konten promosi yang } \\
\text { dapat meningkatkan minat } \\
\text { wisatawan untuk mengunjungi } \\
\text { destinasi wisata di Kabupaten } \\
\text { Klungkung. } \\
\text { b. Mengikuti perkembangan tren } \\
\text { pariwisata di masa new normal seperti } \\
\text { gerakan work from Bali (WFB) dan } \\
\text { mengaitkannya dengan konten promosi } \\
\text { yang dibuat. } \\
\text { c. Mengikuti kelas atau webminar } \\
\text { mengenai meningkatkan skill } \\
\text { dalam promosi seperti copywriting } \\
\text { dalam mempromosikan suatu } \\
\text { produk, jasa, dan destinasi wisata. }\end{array}$ \\
\hline & $\begin{array}{l}\text { 3) JBK lebih aktif dalam mencari } \\
\text { informasi mengenai } \\
\text { kesempatan-kesempatan } \\
\text { melakukan kerjasama di } \\
\text { bidang promosi wisata dengan } \\
\text { lembaga/instansi di luar Dinas } \\
\text { Pariwisata }\end{array}$ & $\begin{array}{l}\text { a. Mencari tahu kegiatan-kegiatan } \\
\text { mengenai promosi kepariwisataan } \\
\text { yang akan dilakukan oleh } \\
\text { lembaga/instansi di luar Dinas } \\
\text { Pariwisata } \\
\text { dan berupa untuk berpartisipasi di } \\
\text { dalamnya }\end{array}$ \\
\hline 3 & $\begin{array}{l}\text { Strategi WO } \\
\text { 1) Membuat perencanaan upaya } \\
\text { promosi yang lebih intens pada } \\
\text { sosial media yang dimiliki }\end{array}$ & $\begin{array}{ll}\text { a. } & \text { Menjadwalkan waktu untuk } \\
\text { mengunggah media atau konten yang } \\
\text { terkait dengan kepariwisataan di } \\
\text { sosial pada masing-masing sosial } \\
\text { media yang dimiliki } \\
\text { b. Membuat tim yang bertanggung } \\
\text { jawab untuk mengelola masing- } \\
\text { masing sosial media yang } \\
\text { dimiliki oleh JBK }\end{array}$ \\
\hline & $\begin{array}{l}\text { 2) Mengawasi setiap } \\
\text { pemberitahuan yang } \\
\text { didapatkan dari media promosi } \\
\text { yang diunggah ke berbagai } \\
\text { akun sosial media }\end{array}$ & $\begin{array}{l}\text { a. Setiap orang dari tim yang bertanggung } \\
\text { jawab pada sosial media yang dimiliki } \\
\text { oleh JBK harus fokus dalam memantau } \\
\text { aktivitas- aktivitas yang terjadi pada } \\
\text { sosial media yang dikelola. }\end{array}$ \\
\hline
\end{tabular}




\begin{tabular}{|c|c|c|}
\hline & $\begin{array}{l}\text { 3) Mengadakan pertemuan rutin bagi } \\
\text { anggota JBK dalam membahas } \\
\text { upaya promosi yang dapat } \\
\text { dilakukan. }\end{array}$ & $\begin{array}{l}\text { a. Mendiskusikan mengenai konten apa } \\
\text { yang dapat dibuat dan dikembangkan } \\
\text { sebagai media promosi. } \\
\text { b. Mengadakan Evaluasi mengenai trafik } \\
\text { kunjungan pada sosial media yang } \\
\text { dimiliki oleh JBK dengan kurun } \\
\text { waktu tertentu. }\end{array}$ \\
\hline & $\begin{array}{l}\text { 4) Membentuk divisi-divisi khusus } \\
\text { dalam pembuatan media } \\
\text { promosi, pengelolaan sosial } \\
\text { media, dan komunikator } \\
\text { dengan stakeholder di bidang } \\
\text { pariwisata. }\end{array}$ & $\begin{array}{l}\text { a. Membentuk divisi khusus yang bertugas } \\
\text { untuk: } \\
\text { - Mengelola, } \\
\text { - Melakukan riset untuk destinasi } \\
\text { wisata yang berpotensi untuk } \\
\text { dipromosikan, } \\
\text { - Memproduksi konten promosi wisata } \\
\text { yang akan diunggah. }\end{array}$ \\
\hline & $\begin{array}{l}\text { 5) Membentuk kerjasama yang } \\
\text { dapat memberikan keuntungan } \\
\text { bagi JBK dan stakeholder di } \\
\text { bidang pariwisata }\end{array}$ & $\begin{array}{l}\text { a. Menawarkan kepada pengusaha } \\
\text { pariwisata untuk melakukan } \\
\text { endorsement atau promosi berbayar } \\
\text { pada akun media sosial yang dimiliki } \\
\text { JBK }\end{array}$ \\
\hline 4 & $\begin{array}{l}\text { Strategi WT } \\
\text { 1) Memberikan edukasi mengenai } \\
\text { perkembangan Covid-19 dan } \\
\text { kepriwisataan di Bali melalui } \\
\text { media sosial }\end{array}$ & $\begin{array}{l}\text { a. Memberikan informasi mengenai } \\
\text { destinasi wisata serta penyedia } \\
\text { layanan wisata yang telah memiliki } \\
\text { sertifikat CHSE dan telah } \\
\text { meyediakan pelayanan yang sesuai } \\
\text { dengan } \\
\text { protokol kesehatan yang berlaku } \\
\end{array}$ \\
\hline & $\begin{array}{l}\text { 2) Mengikuti webminar mengenai } \\
\text { kepariwisataan dan strategi } \\
\text { promosi pariwisata digital } \\
\text { serta pada masa new }\end{array}$ & $\begin{array}{l}\text { a. Mengikuti webminar yang diadakan } \\
\text { baik dari kementerian pariwisata, } \\
\text { instansi/lembaga pariwisata terkait } \\
\text { maupun webminar uang } \\
\text { diselenggarakan oleh instansi } \\
\text { pendidikan pariwisata. } \\
\text { b. Mengikuti webminar mengenai } \\
\text { promosi terutama digital } \\
\text { marketing }\end{array}$ \\
\hline & $\begin{array}{l}\text { 3) Melakukan sharing session dengan } \\
\text { Jegeg Bagus di Kabupaten lain } \\
\text { mengenai upaya promosi } \\
\text { pariwisata di Kabupaten maing- } \\
\text { masing }\end{array}$ & $\begin{array}{l}\text { a. Menjadwalkan pertemuan dengan } \\
\text { Jegeg Bagus atau duta wisata di } \\
\text { Kabupaten lain di Bali untuk } \\
\text { membahas upaya-upaya promosi yang } \\
\text { dapat dilakukan di Kabupaten masing- } \\
\text { masing } \\
\text { b. Membahas kemungkinan untuk }\end{array}$ \\
\hline
\end{tabular}




\begin{tabular}{|l|l|}
\hline & $\begin{array}{l}\text { melakukan kolaborasi antar } \\
\text { Kabupaten untuk } \\
\text { mempromosikan destinasi wisatanya } \\
\text { masing- masing }\end{array}$ \\
\hline
\end{tabular}

Berdasarkan matriks SWOT yang telah dijabarkan, terdapat beberapa pilihan peran strategis yang dapat dipilih. Rancangan peran strategis bersifat intensif yang dapat dipilih adalah:

1. Mengintensifikasikan upaya promosi dengan perkembangan teknologi dan informasi merupakan upaya promosi yang sangat efektif dimana JBK dapat mempromosikan destinasi wisata di Kabupaten Klungkung secara digital. Langkah yang tepat untuk memaksimalkan potensi untuk mempromosikan destinasi wisata dengan memanfaatkan perkembangan teknologi dan informasi yaitu dengan membuat divisi-divisi khusus dalam pembuatan konten promosi maupun topik lain yang terkait, serta pengelolaan yang responsif di setiap sosial media yang dimiliki.

2 Memberikan edukasi dan informasi melalui berbagai media promosi bahwa destinasi pariwisata di Kabupaten Klungkung telah menerapkan protokol kesehatan sesuai dengan aturan yang berlaku dapat menjadi salah satu peran strategis bagi JBK pada masa new normal. Dengan edukasi dan informasi yang diberikan, maka khalayak yang dijangkau dapat merencanakan mengenai kunjungan mereka ke Kabupaten Klungkung.

3. Mengadakan kerja sama dengan stakeholder di bidang pariwisata. Kemudahan dalam menjalin koneksi dengan instansi atau lembaga pariwisata akan menjadi salah satu keuntungan JBK. Dengan kemampuan komunikasi serta kualitas charming, smart and hospitable, JBK dapat memaksimalkan peran mereka dalam fungsi public relation sebagai duta wisata. 
4. Membuat suatu bentuk promosi yang lebih persuasif bagi calon wisatawan yang berniat membeli produk/jasa dari sponsor yang bekerjasama dengan JBK. JBK dapat menawarkan kerjasama dengan pengusaha di bidang pariwisata yang dapat menguntungkan kedua belah pihak, seperti mengadakan promosi menggunakan kode referral untuk potongan harga, dari produk/jasa yang dipromosikan.

5. Mengadakan pertemuan rutin bagi anggota JBK dalam membahas upaya promosi yang dapat dilakukan. JBK dapat membahas peluang-peluang serta kendala yang mereka miliki agar dapat dituntaskan bersama.

6. Evaluasi Kinerja JBK dapat melakukan evaluasi dalam kurun waktu tertentu. Dengan evaluasi ini maka JBK dapat mengukur dan merefleksikan upaya promosi yang telah mereka lakukan selama ini. Evaluasi ini bertujuan agar JBK dapat melakukan refleksi atas upaya promosi yang selama ini dilakukan.

\section{Simpulan dan Saran}

JBK telah berperan dalam upaya mempromosikan destinasi wisata di Kabupaten Klungkung pada masa new normal melalui program kerja berupa pembuatan video promosi destinasi wisata di Kabupaten Klungkung yang diunggah pada media sosial yang dimiliki oleh JBK. Upaya promosi juga terlihat saat proses pemilihan JBK 2020 yang menyertakan pembuatan video promosi sebagai salah satu syarat untuk mengikuti pemilihan. Video-video tersebut diunggah ke akun sosial media JBK. Pembuatan video promosioleh JBK didanai dengan melakukan kerjasama berupa sponsorship dengan berbagai pengusaha di bidang pariwisata.

Kendala yang dihadapi oleh Jegeg Bagus Klungkung dalam mempromosikan destinasi wisata di Kabupaten Klungkung pada masa new normal terdiri dari satu kendala ekternal dan tiga kendala internal. Kendala eksternal yang dihadapi oleh JBK adalah penyesuaian dengan masa new normal dan penyebaran virus Covid-19. Kendala 
internal yang dihadapi oleh JBK adalah masalah pendanaan, bentuk organisasi yang belum kuat dan kepentingan serta kesibukan pribadi masing-masing anggota.

Peran strategis promosi destinasi wisata pada masa new normal yang tepat berdasarkan analisis IFAS dan EFAS adalah grow and build (tumbuh dan berkembang) dan dapat dilaksanakan melalui 14 poin peran strategis dan 6 strategi yang bersifat intensif.

\section{Ucapan Terima Kasih}

Penulis menyampaikan ucapan terima kasih kepada Dr. Drs. I Putu Anom, M.Par. selaku Pembimbing I, dan Dr. Ida Bagus Ketut Surya, SE., MM. selaku Pembimbing II, dalam memberikan bimbingan selama penulisan tesis saat menempuh pendidikan di Program Studi Magister Kajian Pariwisata Universitas Udayana. Ucapan terima kasih juga disampaikan kepada Gde Indra Bhaskara, M.Sc., Ph.D., Ni Made Sofia Wijaya, SST.Par., M.Par., Ph.D., Dr. Ni Putu Ratna Sari, SST.Par., M.Par. selaku penguji tesis yang telah memberikan masukan dan saran. Penulis juga menyampaikan terima kasih kepada responden penelitian, teman-teman kuliah, staf sekretariat, dan keluarga yang telah mendukung penyusunan tesis dan artikel ini

\section{Daftar Pustaka}

David, F., R. 2014. Analisis SWOT Teknik Membedah Kasus Bisnis. Jakarta: Gramedia Pustaka Utama.

Diyatma, A., \& Rahayu, I. 2017. Pengaruh Promosi Melalui Media Sosial Instagram Terhadap Keputusan Pembelian Produk Saka Bistro \& Bar. eProceedings of Management, 4(1).

Fajar, W., H., 2020. Mengenal Konsep New Normal. [diakses 2020, Oktober 10]. Tersedia pada: https://indonesia.go.id/ragam/komoditas/ekonomi/mengenalkonsep-new-normal 
Gary, A., dan Kotler, P. 2012. Dasar-Dasar Pemasaran. Jilid I, Alih Bahasa Alexander Sindoro dan Benyamin Molan. Jakarta: Penerbit Prenhalindo.

JBK. [youtube: Jegeg Bagus Klungkung]. 2021. Beranda. https://www.youtube.com/channel/UCjVOutF0hsnlxuvnc6eVnWg [diakses 2021, April 30].

Jegeg Bagus Bali. 2021. Sejarah dan Makna Logo. [diakses 2020, Nopember 24]. Tersedia pada: https://jegegbagusklungkung.org/sejarah-dan-makna-logo/

Klungkungkab. 2020. Bupati Suwirta Harapkan Jegeg Bagus Tidak Hanya Bermodal Kecantikan dan Ketampanan. [diakses 2020, Desember].Tersedia pada: https://klungkungkab.go.id/berita/detail/bupati-suwirta-harapkan-jegegbagus-tidak- hanya-bermodal-kecantikan-dan-ketampanan

Rangkuti, F. 2018. Analisis SWOT Teknik Membedah Kasus Bisnis. Jakarta: Gramedia Pustaka Utama.

Ruslan, R. 2016. Manajemen Public Relations \& Media Komunikasi. Jakarta: PT. Raja Grafindo Persada.

Satriawan. 2013. Hakikat Pemilihan Duta Wisata. Surakarta: Cendana Offset.

Suneth, M. 2017. Penerapan Sistem Just In Time dalam Meningkatkan Produktivitas Perusahaan pada PT. Cipta Beton Sinar Perkasa di Makassar. (Skripsi). Universitas Islam Negeri Alauddin Makassar.

Undang-Undang Kepariwisataan No. 10. Tahun 2009.

Wattimena, P. M., et al. 2015. Peran Mas dan Mbak Duta Wisata dalam Mempromosikan Kota Salatiga. (Skripsi). Universitas Kristen Satya Wacana.

\section{Profil Singkat Penulis}

Luh Ade Syah Sugiarni lahir di Gianyar, 8 Februari 1996 dan tinggal di Jalan Raya Ketewel, Desa Ketewel, Kecamatan Sukawati. Beliau menempuh Pendidikan D4 Manajemen Akuntansi Hospitaliti dari Sekolah Tinggi Pariwisata Nusa Dua Bali (saat ini bernama Politeknik Pariwisata Bali) dan menamatkan S2nya di Fakultas Pariwisata Universitas Udayana. 
Dr. Drs. I Putu Anom, M.Par. merupakan mahasiswa angkatan pertama program Magister Pariwisata di Universitas Udayana dan merupakan Dosen dari Fakultas Pariwisata Universitas Udayana.

Dr. Ida Bagus Ketut Surya, SE., MM adalah dosen Prodi Magister Kajian Pariwisata Universitas Udayana. Selain itu, beliau juga aktif megajar sebagai dosen Program Studi Manajemen pada Fakultas Ekonomi dan Bisnis Universitas Udayana, Prodi Magister Manajemen, Prodi Magister Akuntansi dan Prodi Doktor Ilmu Manajemen Universitas Udayana. Beliau lahir di Desa Lukluk, Kecamatan Mengwi, Kabupaten Badung. Program pendidikan yang ditempuh yaitu Sarjana (S1) di Manajemen Fakultas Ekonomi dan Bisnis Universitas Udayana, jenjang (S2) di Magister Manajemen Konsentrasi Bisnis Pariwisata di Universitas Udayana, dan jenjang Doktor (S3) di Program Doktor Ilmu Manajemen Universitas Brawijaya Malang. Email: idabgssurya@unud.ac.id. 